\title{
Quercus delgadoana (Fagaceae), a New Species from the Sierra Madre Oriental, Mexico
}

\author{
Susana Valencia Avalos \\ Herbario de la Facultad de Ciencias, UNAM, Apartado Postal 70-181, Delegación Coyoacán, \\ 04510 México, D.F., México.sva@hp.fciencias.unam.mx
}

Kevin C. Nixon

L. H. Bailey Hortorium, Cornell University, Ithaca, New York 14853-4301, U.S.A. kcn2@cornell.edu

Lawrence M. Kelly

The New York Botanical Garden, 200th Street \& Kazimiroff Boulevard, Bronx, New York 10458-5126, U.S.A. lkelly@nybg.org

Abstract. Quercus delgadoana S. Valencia, Nixon \& L. M. Kelly (Fagaceae), a new species from the states of Hidalgo, Puebla, and Veracruz in the Sierra Madre Oriental, Mexico, is described and illustrated. We discuss its morphological similarity to $Q$. eugeniifolia Liebm., Q. sapotifolia Liebm., $Q$. salicifolia Née, Q. laurina Bonpl., and Q. affinis Scheidw., with which it shares narrowly lanceolate leaves and fasciculate stipitate trichomes in the axils of the secondary veins on the underside of the lamina. A dichotomous key is provided to distinguish these species.

Resumen. Se describe e ilustra Quercus delgadoana S. Valencia, Nixon \& L. M. Kelly (Fagaceae), una especie nueva de los estados de Hidalgo, Puebla y Veracruz en la Sierra Madre Oriental, México. Se discute su similitud morfológica con Q. eugeniifolia Liebm., Q. sapotifolia Liebm., Q. salicifolia Née, Q. laurina Bonpl. y Q. affinis Scheidw., con las que comparte la forma lanceolada de las hojas y la presencia de tricomas fasciculados estipitados en las axilas de las venas secundarias en el envés. Se presenta una clave dicotómica para su identificación.

Key words: Fagaceae, IUCN Red List, Mexico, Quercus, Sierra Madre Oriental.

A review of herbarium specimens for the genus Quercus L. (Fagaceae), particularly for red oaks in section Lobatae Loudon, led to the discovery of an undescribed oak species. The new species grows in the Sierra Madre Oriental, in the states of Hidalgo, Puebla, and Veracruz. Based on the narrow, lanceolate, glabrate leaves, specimens of the new species had often been misidentified as other species, including Q. eugeniifolia Liebm., which has a known range restricted to Central America (Costa Rica and Panama); Q. salicifolia Née, endemic to the Sierra Madre del Sur; Q. sapotifolia Liebm. from Central America and the Sierra Madre Oriental in Mexico; and even Q. laurina Bonpl. from the Sierra Madre del Sur and the Trans-Mexican Volcanic Belt or $Q$. affinis Scheidw. distributed along the Sierra Madre Oriental and to the east of the Trans-Mexican Volcanic Belt. We visited populations of Q. delgadoana S. Valencia, Nixon \& L. M. Kelly in the field and compared this species with the type specimens and photographs, topotypes, and original descriptions of Q. eugeniifolia, Q. salicifolia, Q. sapotifolia, $Q$. laurina, and Q. affinis (Née, 1801; Humboldt \& Bonpland, 1809; Scheidweiler, 1837; Liebmann, 1854). This revealed the characters that uniquely differentiate Q. delgadoana, and a dichotomous key is provided to distinguish these six similar species.

Key for Six Quercus Species in Mexico and Central AMERICA

la. Fruits with annual maturation.

2a. Abaxial leaf surface glabrous or sometimes with some stellate trichomes at the base; secondary veins 12 to 15 on each side ..................... Qugeniifolia

2b. Abaxial leaf surface with some glandular trichomes and with fasciculate trichomes in the secondary vein axils; secondary veins 10 to 14 on each side.

3a. Acorns pubescent; leaves lanceolate or elliptic; secondary veins nearly flat on the abaxial leaf surface; apex acute; endemic to the Pacific slope of the Sierra Madre del Sur ........ Q. salicifolia

3b. Acorns glabrate; leaves oblanceolate to obovate or elliptic; secondary veins slightly impressed on the abaxial leaf surface; apex obtuse to rounded; south- 
eastern Mexico and Central America ......................... Q. sapotifolia

1b. Fruits with biennial maturation.

4a. Secondary veins 14 to 20 on each side, impressed on the adaxial leaf surface; blade margin revolute; adaxial leaf surface without stellate trichomes ............. Q. delgadoana

4b. Secondary veins 5 to 10 on each side, nearly flat or slightly raised on the adaxial leaf surface; blade margin not revolute; adaxial leaf surface with some stellate trichomes toward the base.

5a. Buds ovoid to globose; abaxial leaf surface with some glandular trichomes; altitudinal range $1600-3650 \mathrm{~m}$; Sierra Madre del Sur and the Trans-Mexican Volcanic Belt .............. Q. laurina

5b. Buds conical; abaxial leaf surface without glandular trichomes; altitudinal range 1200-2800 m; Sierra Madre Oriental and to the east of the TransMexican Volcanic Belt ........ Q. affinis

Quercus delgadoana S. Valencia, Nixon \& L. M. Kelly, sp. nov. TYPE: Mexico. Hidalgo: Mpio. Tlanchinol, Km 165 de la carr. TlanchinolTampico, ca. $5 \mathrm{~km}$ al sur de la desviación de Lontla, $21^{\circ} 00^{\prime} \mathrm{N}, 98^{\circ} 39^{\prime} \mathrm{W}, 1540 \mathrm{~m}, 23$ Oct. 2008, S. Valencia A., A. Coombes \& K. Vega 3748 (holotype, FCME; isotypes, BH, HUAP, K, MEXU, MO, NY). Figure 1.

Haec species inter congeneros Querci L. sect. Lobatarum Loudon foliis angustis lanceolatis glabratis praeditos quoad fructus maturationem biennem Querco affini Scheidw. et $Q$. laurinae Bonpl. simillima, sed ab eis lamina foliari venis secondariis 14- ad 20-jugatis adaxialiter impressis, margine revoluta atque trichomatibus stellatis adaxialiter carente distinguitur.

Trees to $25 \mathrm{~m}$ high, trunk $0.5-1.2 \mathrm{~m}$ diam.; branchlets (1.8-)2-3(-4) mm thick, glabrous, lenticels inconspicuous; buds (0.6-) $1-4 \times(0.7-) 1-2.5$ $\mathrm{mm}$, conical, glabrous, bud scales ovate or long ovate, with ciliate margin; stipules deciduous before the leaves fully develop. Mature leaves with petioles 2-6 $\times 1.1-1.8 \mathrm{~mm}$, glabrous, dark toward the base; blades coriaceous, glaucous, narrowly oblong, elliptic, or lanceolate, $7-18.5 \times 1.5-4(-5.4) \mathrm{cm}$; base cuneate or rounded; margin entire, slightly thickened and revolute; blade apex acute, to acuminate and aristate; secondary veins (9 to) 14 to 20 on each side, parallel, straight or slightly curved upward, branched and anastomosing near the margin; adaxial leaf surface glabrous, secondary veins impressed, sometimes almost inconspicuous; abaxial leaf surface slightly paler than adaxial leaf surface, usually glabrous, sometimes with tufts of fasciculate stipitate trichomes in the axils of secondary veins, epidermis slightly papillose, middle and secondary veins slightly raised, tertiary veins flat or slightly raised. Pistillate catkins axillary; pistillate flowers on a short stalk $1.5-8 \mathrm{~mm}$, with 1 or 2 distal flowers; perianth free, forming a flange. Staminate catkins not seen. Fruit biennial, solitary or in pairs at the end of a glabrous peduncle $5.5-17 \times 1.6-4.5 \mathrm{~mm}$; cupule obconic to slightly turbinate, 6-15 $\times 3-8 \mathrm{~mm}$, margin not inrolled; scales ovate, canescent basally, the margins \pm glabrous; acorn ovoid, with tomentose endocarp and glabrous exocarp, $18.3-22.9 \times 10.8-13 \mathrm{~mm}$.

Distribution, habitat, and phenology. Quercus delgadoana is endemic to the Sierra Madre Oriental, Mexico, with populations in the states of Hidalgo, Puebla, and Veracruz. The new species has been collected in montane cloud forest and humid forests of Quercus at altitudes of $1400-2210 \mathrm{~m}$. It is commonly found with Fagus grandifolia Ehrh. subsp. mexicana (Martínez) E. Murray, Q. affinis, Q. lancifolia Shltdl. \& Cham., Alnus jorullensis Kunth, Liquidambar styraciflua L., and occasionally with $Q$. corrugata Hook., Q. cortesii Liebm., and Q. hirtifolia M. L. Vázquez, S. Valencia \& Nixon. Flowers may be produced in March, but only pistillate flowers were observed; fruits can be found in October and November.

IUCN Red List category. According to IUCN Red List criteria (IUCN, 2001), Quercus delgadoana is here given a preliminary classification of Endangered (EN). This species grows in the humid forests of eastern Mexico, in cloud forest communities that are highly disturbed due to the extraction of firewood, the establishment of coffee plantations, and the clearance of forest for pasture. A decline in its populations of more than $50 \%$ is projected to take place as a result of losses to suitable habitat that have already been sustained, as well as potential future loss of habitat.

Etymology. Quercus delgadoana is named in honor of Alfonso Delgado Salinas (Instituto de Biología, UNAM), in recognition of his diverse contributions to plant taxonomy and the training and motivation he has given to so many students in this area of study.

Relationships. The aristate leaf apices, the pistillate flowers with a free perianth forming a skirt or flange, and the tomentose endocarp of the acorn support the assignment of Quercus delgadoana to Quercus sect. Lobatae (sensu Nixon, 1993).

The most important character that differentiates Quercus delgadoana from Q. eugenïfolia, Q. salicifolia, and Q. sapotifolia is that the latter three have fruits that mature annually, while fruits of $Q$. delgadoana mature biennially. However, in $Q$. delgadoana, this character is sometimes masked 


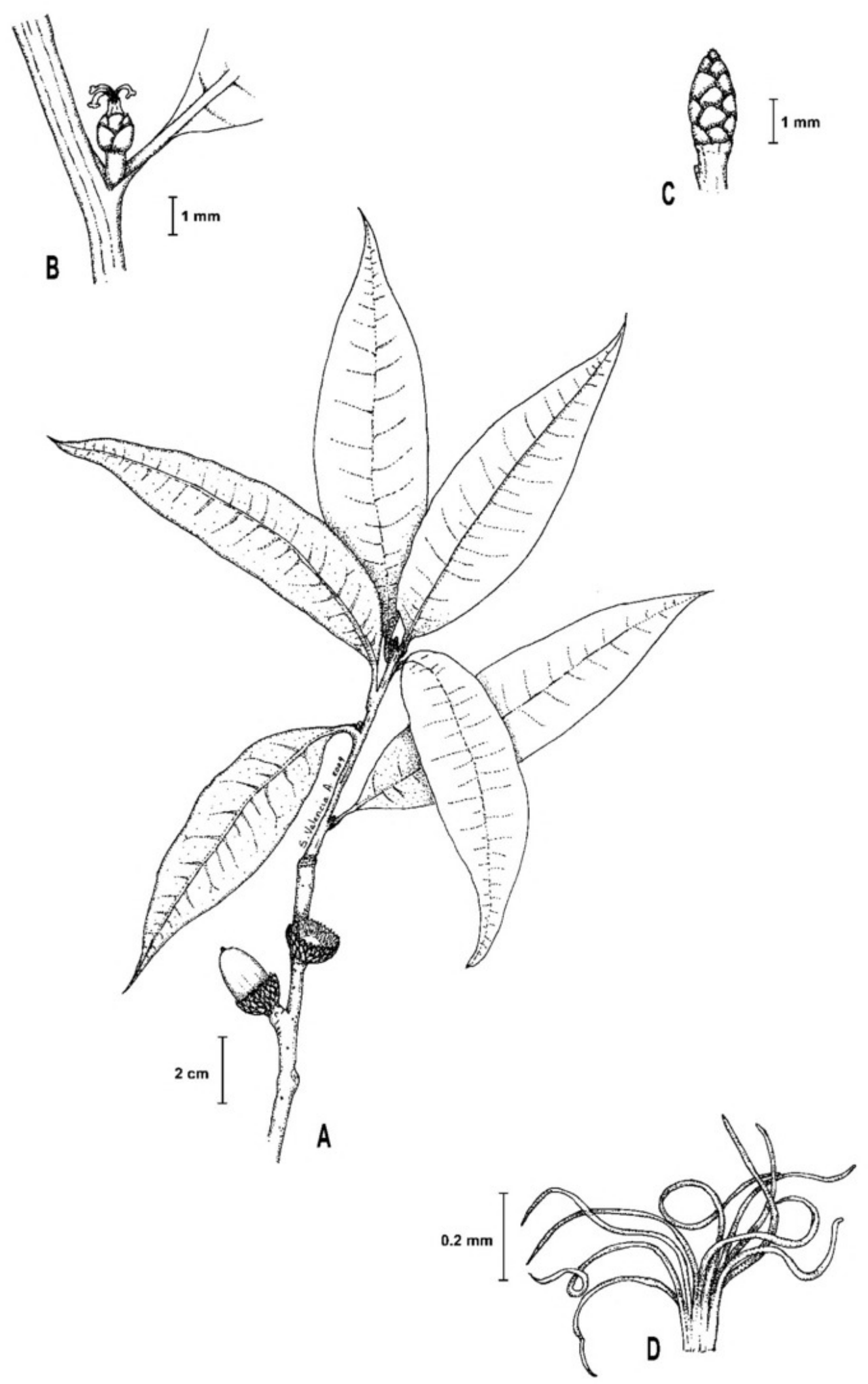

Figure 1. Quercus delgadoana S. Valencia, Nixon \& L. M. Kelly. -A. Branchlet with leaves and fruit. -B. Pistillate flower. -C. Terminal bud. - D. A fasciculate trichome from one of the secondary vein axils. Drawn from the holotype $S$. Valencia A., A. Coombes y K. Vega 3748 (FCME).

because new leaves, shoots, and flowers do not develop every year. Because the fruits take two years to mature and are presented on the terminal twigs, this may give the false impression of annual maturation. Fruits with biennial maturation were observed in the field in two populations of $Q$. delgadoana found in Xochicoatlán and near Tlanchinol, both in the state of Hidalgo. 
Additionally, the entire and revolute leaf margins, the parallel secondary veins, and the lack of glandular trichomes on the abaxial leaf surface distinguish Quercus delgadoana from Q. salicifolia. Quercus sapotifolia can be distinguished by the broadly or narrowly rounded and aristate leaf apex and the smaller acorn to $15 \times 7 \mathrm{~mm}$. The new species further differs from $Q$. laurina and $Q$. affinis in the impressed secondary veins on the adaxial leaf surface, with 14 to 20 veins on each side (vs. these veins not impressed and 5 to 9 veins per side in $Q$. affinis and 6 to 10 veins on each side in Q. laurina), the revolute leaf margins (vs. leaf margins not revolute), and the lack of stellate trichomes on the adaxial leaf surface (vs. adaxial leaf surface with some stellate trichomes toward the base).

Paratypes. MEXICO. Hidalgo: Mpio. Lolotla, a 1.84 km SE de Tenango, 20 $51^{\prime} 23^{\prime \prime} \mathrm{N}, 98^{\circ} 41^{\prime} 55^{\prime \prime} \mathrm{W}, 15$ Apr. 2001, A. Ponce V. 74 (FCME); a $2.82 \mathrm{~km}$ SO de Chalma, $20^{\circ} 51^{\prime} 5^{\prime \prime} \mathrm{N}, 98^{\circ} 40^{\prime} 52^{\prime \prime} \mathrm{W}, 26$ Oct. 2001, A. Ponce V. 207 (FCME); Mpio. Tenango de Doria, Agua Fría, aprox. $500 \mathrm{~m}$ $\mathrm{E}$ de El Damo, $20^{\circ} 19^{\prime} 27^{\prime \prime} \mathrm{N}, 98^{\circ} 12^{\prime} 44^{\prime \prime} \mathrm{W}, 29$ Oct. $1993, O$. Alcantara A. 1542 (FCME, MEXU); Agua Fría, aprox. 2.5 $\mathrm{km}$ E de El Damo, $20^{\circ} 19^{\prime} 43^{\prime \prime} \mathrm{N}, 98^{\circ} 11^{\prime} 54^{\prime \prime} \mathrm{W}, 27$ Oct. 1993, O. Alcantara A. 1509, 1517 (FCME); El Damo, aprox. $1 \mathrm{~km} \mathrm{E,} \mathrm{camino} \mathrm{Tenango} \mathrm{de} \mathrm{Doria-San} \mathrm{Nicolás,}$ $20^{\circ} 19^{\prime} 59^{\prime \prime} \mathrm{N}, 98^{\circ} 12^{\prime} 49^{\prime \prime} \mathrm{W}, 27$ June 1993, O. Alcantara A. \& E. Ortiz B. 1140, 1142 (FCME); El Damo, 2 km SE de Tenango de Doria, $20^{\circ} 19^{\prime} 39^{\prime \prime} \mathrm{N}, 98^{\circ} 12^{\prime} 37^{\prime \prime} \mathrm{W}, 12 \mathrm{Mar}$. 1993, I. Luna V., S. Ocegueda C. \& O. Alcantara A. 912 (FCME); El Cirio, aprox. $1.2 \mathrm{~km} \mathrm{O}$ de San Nicolás, $20^{\circ} 19^{\prime} 19^{\prime \prime} \mathrm{N}, 98^{\circ} 12^{\prime} 6^{\prime \prime} \mathrm{W}, 5$ Sep. 1993, I. Luna V., S. Ocegueda C. \& O. Alcantara A. 1465 (FCME); $6 \mathrm{~km} \mathrm{NE} \mathrm{de}$ Agua Zarca, $20^{\circ} 18^{\prime} 55^{\prime \prime} \mathrm{N}, 98^{\circ} 14^{\prime} 23^{\prime \prime} \mathrm{W}, 21$ Oct. 2008, $S$. Valencia A., A. Coombes \& Karla Vega 3722 (FCME, HUAP); Mpio. Tlanchinol, camino a Coatlán, $21^{\circ} 00^{\prime} \mathrm{N}$, $98^{\circ} 30^{\prime} \mathrm{W}, 6$ June 1993, I. Luna, S. Ocegueda, O. Alcantara 793 (FCME); camino Tlanchinol-Coatlán, 205'일. N, 98³6'56"W, 8 Oct. 1992, I. Luna V., S. Ocegueda C. \& O. Alcántara A. 680 (FCME, MEXU), 688 (FCME), I. Luna $V$. \& O. Alcantara A. 691 (FCME); $5 \mathrm{~km}$ al E de Tlanchinol, $20^{\circ} 58^{\prime} 59^{\prime \prime} \mathrm{N}, 98^{\circ} 36^{\prime} 56^{\prime \prime} \mathrm{W}, 14$ Sep. 1991, I. Luna V. 45 (FCME); camino a Lontla, $7 \mathrm{~km}$ al $\mathrm{N}$ de Tlanchinol, $21^{\circ} 2^{\prime} 53^{\prime \prime} \mathrm{N}, 98^{\circ} 39^{\prime} 14^{\prime \prime} \mathrm{W}, 24$ ago. 1997, Alcantara A. \& $R$. Mayorga S. 3355 (FCME); Km 165 de la carr. TlanchinolTampico, aprox. $5 \mathrm{~km} \mathrm{~S}$ de la desviación de Lontla, $21^{\circ} 00^{\prime} \mathrm{N}, 98^{\circ} 39^{\prime} \mathrm{W}, 1540 \mathrm{~m}, 23$ Oct. 2008, S. Valencia A., A. Coombes \& K. Vega 3747, 3749 (BH, FCME, HUAP);
Mpio. Tlahuelompa, aprox. $1 \mathrm{~km} \mathrm{E}$ sobre la desviación a Tlahuelompa, $20^{\circ} 37^{\prime} 51^{\prime \prime} \mathrm{N}, 98^{\circ} 36^{\prime} 47^{\prime \prime} \mathrm{W}, 22$ Oct. 2008, $S$. Valencia A., A. Coombes \& K. Vega 3741 (FCME, HUAP); Mpio. Xochicoatlán, alrededores de Xochicoatlán, 29 June 1997, S. Valencia A. 1341, 1342, 1343, 1344, 1345, 1346, $1347,1348,1349,1350,1351,1353,1354,1355,1356$ (FCME), 29 June 1997, S. Valencia A. 1352 (FCME, MO). Puebla: Mpio. Zacatlán, Jilotzingo, 29 Jan. 1991, Martínez Murillo Ma. E. 93, 99, 112 (FCME, MEXU); Xilocuautla, F. Miranda 3128 (MEXU); Mpio. Hueytamalco, $7 \mathrm{~km} \mathrm{~N}$ of Teziutlan on hwy. from Teziutlan to Tlapacoyan, $19^{\circ} 52^{\prime} 22^{\prime \prime} \mathrm{N}, 97^{\circ} 10^{\prime} 14^{\prime \prime} \mathrm{W}, 16$ Oct. 2000, L. Kelly \& K. C. Nixon 1090, 1091 (MEXU); N of Hueytamalco, $3 \mathrm{~km} \mathrm{~S}$ of Cruz Verde, Km 12 along hwy. from Teziutlan to Tlapacoyan, $19^{\circ} 53^{\prime} 203^{\prime \prime} \mathrm{N}, 97^{\circ} 17^{\prime} 871^{\prime \prime W}, 30$ Sep. 2000, L. Kelly \& K. C. Nixon 1054 (MEXU). Veracruz: Mpio. Acajete, ca. $4 \mathrm{~km}$ E of Acajete, $3 \mathrm{~km}$ above (S of) Plan de Sedeño, $5 \mathrm{~km} \mathrm{~S}$ of hwy. betw. Perote \& Xalapa, 16 Oct. 2000, L. Kelly \& K. C. Nixon 1105 (MEXU).

Acknowledgments. We thank José Antonio Hernández (Microcine Lab, Facultad de Ciencias, UNAM) for assistance in scanning the illustration; Elisabeth Chávez García and Victor Hugo García for comments on an early version of this paper; and A. Coombes, Ross McCauley, Richard Spellenberg, and Victoria C. Hollowell (MO) for their critical reviews of the manuscript.

\section{Literature Cited}

Humboldt, A. V. \& A. Bonpland. 1809. Quercus. Pp. 24-58 in Plantes Équinoxiales, Vol. 2. F. Schoell, Paris.

IUCN. 2001. IUCN Red List Categories and Criteria, Version 3.1. Prepared by the IUCN Species Survival Commission. IUCN, Gland, Switzerland, and Cambridge, United Kingdom.

Liebmann, F. M. 1854. Om Egeslaegten i America. Pp. 159-189 in Oversigt over det Kongelige Danske Videnskabernes Selskabs Forhandlinger og dets Midlemmers Arbeider. Copenhagen.

Née, L. 1801. Descripción de varias especies nuevas de encinos (Quercus de Linneo). Anales Ci. Nat. 3(9): 260276.

Nixon, K. C. 1993. Infrageneric classification of Quercus (Fagaceae) and typification of sectional names. Ann. Sci. Forest. Suppl. 1 (Paris) 50: 25s-34s.

Scheidweiler, M. 1837. Chenes de Mexicque. Hort. Belge 4: 321. 


\section{$2 \mathrm{BHL}$ Biodiversity Heritage Library}

Valencia Avalos, Susana, Nixon, Kevin C, and Kelly, Lawrence M. 2011.

"Quercus delgadoana (Fagaceae), a New Species from the Sierra Madre Oriental, Mexico." Novon a journal of botanical nomenclature from the Missouri Botanical Garden 21(2), 274-277. https://doi.org/10.3417/2009054.

View This Item Online: https://www.biodiversitylibrary.org/item/180102

DOI: https://doi.org/10.3417/2009054

Permalink: https://www.biodiversitylibrary.org/partpdf/218488

\section{Holding Institution}

Missouri Botanical Garden, Peter H. Raven Library

\section{Sponsored by}

Missouri Botanical Garden

\section{Copyright \& Reuse}

Copyright Status: Permission to digitize granted by rights holder

Rights: https://www.biodiversitylibrary.org/permissions

This document was created from content at the Biodiversity Heritage Library, the world's largest open access digital library for biodiversity literature and archives. Visit BHL at https://www.biodiversitylibrary.org. 